\title{
Helicobacter pylori Infection and Risk of Gastric Cancer in Korea: A Quantitative Systematic Review
}

\author{
Jong-Myon Bae, Eun Hee Kim \\ Department of Preventive Medicine, Jeju National University School of Medicine, Jeju, Korea
}

Objectives: In the context of the global decrease in mortality due to gastric cancer, previous studies have reported that the effect of chronic Helicobacter pylori (H. pylori) infection on the incidence of gastric cancer varies among regions. This systematic review was conducted to investigate $H$. pylori as a risk factor for gastric cancer in Korea, where the incidence of gastric cancer is among the highest in the world.

Methods: A search strategy was established to identify articles published in Korean as well as in English. Ultimately, we included observational studies conducted among Korean patients that designed with an age-matched and sex-matched control group that reported the odds ratio associated with H. pylori. Gastric cancer cases were subdivided into overall (OGC), cardia (CGC), non-cardia (NGC), early (EGC), advanced, intestinal (IGC), and diffuse forms of gastric cancer. Summary odds ratios (SORs) with $95 \%$ confidence intervals (Cls) were calculated in the meta-analysis using a random-effect model.

Results: Eleven case-control studies were ultimately selected. H. pylori was associated with an SOR of 1.81 (95\% Cl, 1.29 to 2.54$)$ for OGC. Additionally, statistically significant risks were observed for CGC, NGC, EGC, and IGC.

Conclusions: Chronic H. pylori infection was found to raise the risk of gastric cancer among Koreans, with the highest risk observed for CGC and EGC ( $\mathrm{SOR}=2.88$ for both). Follow-up clinical epidemiologic studies are needed to assess the effects of current treatments aimed at eradicating $H$. pylori infections.

Key words: Stomach neoplasms, Helicobacter pylori, Risk factors, Meta-analysis, Korea

\section{INTRODUCTION}

Gastric cancer is responsible for $8 \%$ of global cancer cases [1]. However, the global death rate due to gastric cancer has

Received: February 26, 2016 Accepted: July 7, 2016

Corresponding author: Jong-Myon Bae, MD, PhD

102 Jejudaehak-ro, Jeju 63243, Korea

Tel: +82-64-755-5567, Fax: +82-64-702-2687

E-mail: jmbae@jejunu.ac.kr

This is an Open Access article distributed under the terms of the Creative Commons Attribution Non-Commercial License (http://creativecommons.org/licenses/by$\mathrm{nc} / 4.0 /$ ) which permits unrestricted non-commercial use, distribution, and reproduction in any medium, provided the original work is properly cited. decreased over the past decades [2-4], which has been explained as resulting from changes in dietary habits and the decreased prevalence of chronic Helicobacter pylori (H. pylori) infections [1,5-7]. The incidence and mortality rates of gastric cancer have also decreased in Korea, where its incidence has been found to be among the highest worldwide $[4,8]$. This trend has likewise been explained by a decrease in the prevalence of H. pylori [2,9].

Since H. pylori was first described in scientific circles in 1984 [10], it has been recognized as the most significant risk factor for the incidence of gastric cancer [4,11-13]. The relative risk ratio of $H$. pylori for gastric cancer was reported to be approximately six in epidemiologic studies performed in the early 
2000 s $[14,15]$. However, a systematic review of studies published through June 2009 found that $H$. pylori infection was associated with a 3.02 times higher risk of non-cardia gastric cancer (NGC) in areas with a high incidence of gastric cancer, which is approximately $50 \%$ of the risk reported in earlier studies, whereas no statistically significant association was found between $H$. pylori infection and cardia gastric cancer (CGC) [16].

However, only three studies published in English [17-19] were considered in the selection process of the systematic review conducted by Cavaleiro-Pinto et al. [16], and none were published in Korean. Hence, it was necessary to conduct a quantitative systematic review with a search period extending until December 2015 that included articles published in Korean. Thus, the purpose of this study was to conduct a systematic review to investigate the effect of $H$. pylori infection on the incidence of gastric cancer among Koreans.

\section{METHODS}

\section{Search Strategy and Study Selection}

We searched for previous studies on H. pylori infection as a risk factor for gastric cancer among Koreans. The search formula was [(gastric OR stomach) AND (cancer OR neoplasms) AND (Helicobacter OR pylori) AND (Korea OR Korean)]. In addition to PubMed, we used the KoreaMed, the Korean Medical Database (KMBase), the Korean Studies Information Service System (KISS), and the Research Information Sharing Service (RISS4U). In addition to the publications that were retrieved, the cited articles were separately added to the selection list.

After removing duplicates from the lists, laboratory studies, studies with different hypotheses, reviews, and systematic reviews were eliminated. Studies including the same gastric cancer patients in specific cohorts or medical institutions with overlapping time periods were considered to be duplicates and were eliminated, while we selected the study that included the greatest number of gastric cancer patients selected as representative of a given set of patients. Thus, the final selection criteria for our meta-analysis were as follows: (1) an article must have been an analytical epidemiology study on gastric cancer among Koreans; (2) information was provided about the risk associated with $\mathrm{H}$. pylori; (3) if it was a case-control study, the control group was selected through age-matching and sex-matching.

The eligibility of each abstract or full-text article was as- sessed independently in a standardized manner by two reviewers. Disagreements between reviewers were resolved by consensus.

\section{Information Extraction}

The odds ratios (ORs) for gastric cancer incidence associated with $\mathrm{H}$. pylori infection and the $95 \%$ confidence intervals (Cls) were extracted. The standard error of the logarithm of the OR was calculated by applying the formula [ $\left.\ln \left(\mathrm{OR}_{\text {upper }}\right)-\ln \left(\mathrm{OR}_{\text {lower }}\right)\right]$ /3.92 based on the $95 \% \mathrm{Cl}$ [20]. The ORs specified for each study were divided into two types: frequency-matched (FORs), which were calculated based on frequencies after sex-matching and age-matching, and adjusted (AORs), which were adjusted for other covariates after the matching process.

Information related to how $H$. pylori infections were determined and the types of gastric cancer types assessed was extracted. The cases were divided into early gastric cancer (EGC) and advanced gastric cancer (AGC) depending on the degree of gastric cancer progression, and when that information was not available, cases were categorized as overall gastric cancer (OGC). Cases were categorized as CGC and NGC according to the region of incidence. Cases were also categorized according to their histopathology as diffuse-type (DGC), intestinal-type (IGC), and mixed-type (MGC). Cases were classified according to the measurement method of $H$. pylori infection, depending on whether an enzyme-linked immunosorbent assay for immunoglobulin $\mathrm{G}$ antibodies within the serum was used or Campylobacter-like organism tissue staining using urease.

\section{Statistical Analysis}

Heterogeneity was defined as a Higgins' $\left.\right|^{2}$ value $>50 \%$ [21] A meta-analysis was conducted using a random effect model to calculate the summary odds ratio (SORs) and 95\% Cls. Egger's test for small-study effects was used when applicable [22]. Subgroup analyses were conducted for gastric cancer type, $H$. pylori measurement method, and OR type. A $p$-value $<0.05$ was considered to indicate statistical significance, and Stata/ SE version 14.0 (StataCorp., College Station, TX, USA) was used for meta-analysis and forest plot.

\section{RESULTS}

\section{Final Selection of Related Articles}

A list of 4239 articles was retrieved from our electronic search of KoreaMed, KMBase, KISS, RISS4U, and PubMed. Fifty- 
Table 1. Articles selected and excluded due to including the same gastric cancer cases

\begin{tabular}{lcc}
\hline \multirow{2}{*}{ Sources } & \multicolumn{2}{c}{ Reference number } \\
\cline { 2 - 3 } & Selected & Excluded \\
\hline Korean Multi-Center Cancer Cohort & 23 & $19,24-28$ \\
Seoul Bundang Hospital & 29 & $30-35$ \\
National Cancer Center Hospital & 36 & 37,38 \\
Hallym/Hanyang University Hospital & 39 & 40,41 \\
\hline
\end{tabular}

seven additional articles were identified by a manual search of the references. When duplicates were eliminated from the combined list, 1082 abstracts remained. Based on a review of the study titles and abstracts, 381 laboratory studies, 528 studies with different hypotheses, and 117 expert or systematic reviews were eliminated. Once the full texts were obtained, we reviewed 56 articles. Subsequently, we eliminated 10 papers in which the control group was selected without age-matching and sex-matching, 19 papers without information necessary for the meta-analysis, and 16 papers drawing on duplicate patient groups. Ultimately, 11 case-control studies were selected for the meta-analysis (Table 1, Figure 1).

\section{Results of the Meta-analysis}

Table 2 presents the information extracted from the 11 articles, categorized according to the area of incidence, clinical stage, and histological pattern [17,23,29,36,39,42-47]. OGC-related information was obtained from eight articles [17,23,29, $36,39,44-46]$, while four articles contained information on EGC $[36,42,43,47]$, Only one article discussed MGC [36], and MGC was therefore eliminated from the following meta-analysis.

Figures 2 and 3 show forest plots for each gastric cancer type. In the eight OGC articles, H. pylori infection was observed to increase the risk of gastric cancer by 1.81 times $(95 \% \mathrm{Cl}, 1.29$ to $\left.2.54 ; I^{2}=84.4 \%\right)$. The CGC and EGC articles showed the highest SORs ( $\mathrm{SOR}=2.88$ in both), which was a statistically significant finding.

OGC, NGC, DGC, IGC, and EGC showed I-squared values $>75 \%$, and Egger's test was thus performed. All $p$-values for publication bias were confirmed to be $>0.10$, indicating that no small-scale study effects were present (not shown).

Table 3 illustrates the results of subgroup analyses conducted on articles that reported AORs and detected H. pylori infections using serum antibodies. Our findings remained statistically significant for OGC, CGC, and NGC, whereas statistical significance was lost for EGC and DGC in this sub-analysis.

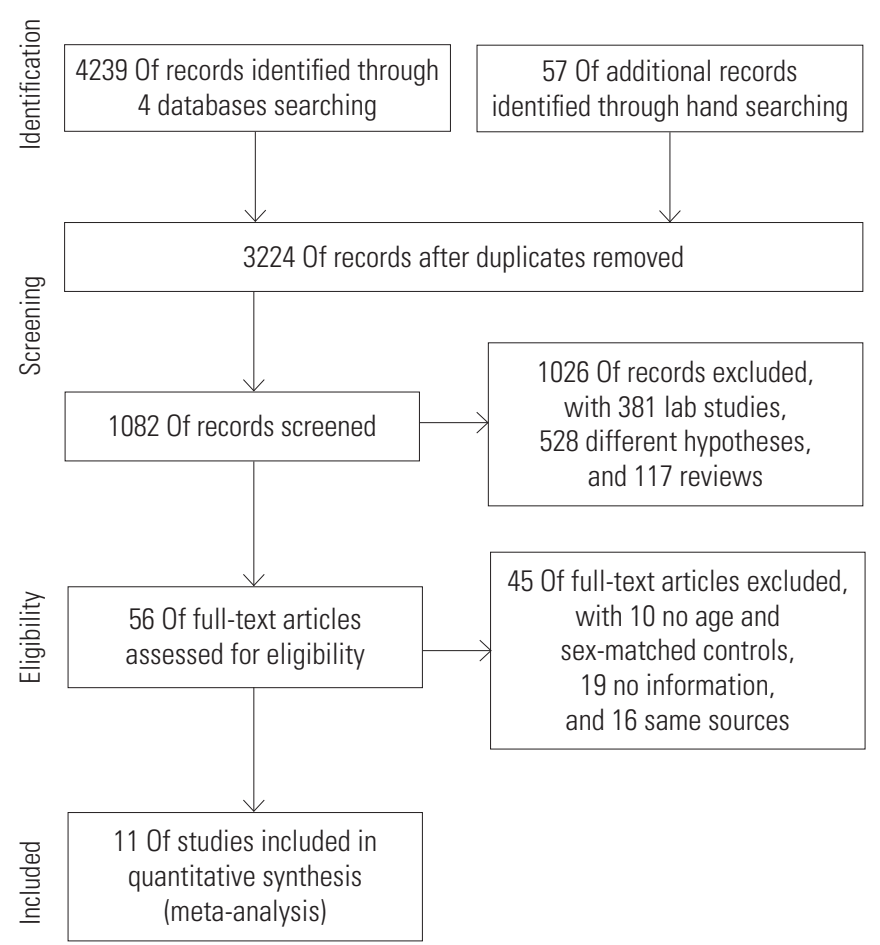

Figure 1. Systematic review flow chart.

\section{DISCUSSION}

Chronic H. pylori infection was confirmed to be a major risk factor for gastric cancer among Koreans, as it was associated with an SOR of 1.81 (95\% Cl, 1.29 to 2.54). Furthermore, for CGC and NGC, the SOR was found to be $2.88(95 \% \mathrm{Cl}, 2.15$ to $3.87)$ and $2.37(95 \% \mathrm{Cl}, 1.32$ to 4.26$)$, respectively, confirming that the area of the incidence of cancer was not significantly affected by $H$. pylori. These SORs are similar to the results reported in the meta-analysis conducted by Cavaleiro-Pinto et al. [16] on high-risk populations. For CGC, the carcinogenic mechanism was confirmed to be distinctly different in the Far East and the West $[2,48,49]$. While Hansen et al. [49] reported that NGC was less common and CGC was more common in the West, this pattern has not been observed among Koreans [50], although additional studies are needed in the future.

Furthermore, IGC has become less common and DGC has become more common in the West [2]. This pattern has not been found among Koreans [50], although IGC has been found to increase with age [51]. The present study showed that $H$. pylori infection significantly raised the risk of IGC (SOR, $1.88 ; 95 \% \mathrm{Cl}, 1.01$ to 3.47$)$, but not the risk of DGC (SOR, 1.58; $95 \% \mathrm{Cl}, 0.63$ to 3.95$)$. Although proposals have been made re- 
Table 2. Summary table of information extracted from the selected case-control studies

\begin{tabular}{|c|c|c|c|c|c|c|c|}
\hline $\begin{array}{l}\text { First author } \\
\text { (year of publication) } \\
\text { [Ref] }\end{array}$ & Inclusion period & $\begin{array}{l}\text { Type of } \\
\text { cancer }\end{array}$ & $\begin{array}{l}\text { No. of cases } \\
\text { / controls }\end{array}$ & $\begin{array}{l}\text { Test for } \\
\text { H. pylori }\end{array}$ & $\begin{array}{c}\text { Type of } \\
\text { OR }\end{array}$ & OR & $95 \% \mathrm{Cl}$ \\
\hline \multirow[t]{4}{*}{ Kim (1997) [17] } & 1994 & 0 & $160 / 160$ & U\&H & $\mathrm{F}$ & 1.39 & $0.89,2.17$ \\
\hline & & C & $12 / 12$ & & $\mathrm{~F}$ & 1.43 & $0.27,7.52$ \\
\hline & & $\mathrm{N}$ & $148 / 148$ & & $\mathrm{~F}$ & 1.39 & $0.88,2.20$ \\
\hline & & $\mathrm{D}$ & $63 / 63$ & & $\mathrm{~F}$ & 1.40 & $0.68,2.87$ \\
\hline \multirow[t]{2}{*}{$\operatorname{Kim}(2000)$ [42] } & Nov 1996 to Jul 1998 & $E$ & $79 / 33$ & $\lg G A b$ & $\mathrm{~F}$ & 0.88 & $0.42,1.83$ \\
\hline & & $A$ & $208 / 33$ & & $\mathrm{~F}$ & 0.72 & $0.32,1.64$ \\
\hline Chang (2002) [39] & May 1997 to Oct 1998 & 0 & $136 / 136$ & $\lg G A b$ & $J$ & 1.82 & $1.10,3.00$ \\
\hline Lee (2003) [43] & Mar 1999 to Sep 1999 & $E$ & $69 / 199$ & $\lg G A b$ & $J$ & 5.30 & $1.70,16.5$ \\
\hline $\operatorname{Kim}(2005)$ [44] & Aug 1997 to Jul 1998 & 0 & $295 / 295$ & $\lg G A b$ & $J$ & 1.71 & $1.13,2.58$ \\
\hline \multirow{6}{*}{ Cho (2010) [36] } & & $A$ & $1575 / 562$ & & $J$ & 2.94 & $2.24,3.85$ \\
\hline & & C & $216 / 562$ & & $J$ & 2.98 & $2.16,4.02$ \\
\hline & & $\mathrm{N}$ & $2603 / 562$ & & $J$ & 3.17 & $2.48,4.04$ \\
\hline & & I & $1349 / 562$ & & $J$ & 3.00 & $2.24,3.93$ \\
\hline & & $\mathrm{D}$ & $974 / 562$ & & $J$ & 3.15 & $2.45,4.05$ \\
\hline & & M & $102 / 562$ & & $J$ & 2.56 & $1.82,3.58$ \\
\hline \multirow[t]{3}{*}{ Chung (2012) [45] } & Jan 2004 to Oct 2010 & 0 & $277 / 1108$ & $\lg G A b$ & $J$ & 1.16 & $0.77,1.76$ \\
\hline & & I & & & $J$ & 1.31 & $0.62,2.86$ \\
\hline & & $\mathrm{D}$ & & & $J$ & 0.81 & $0.45,1.45$ \\
\hline
\end{tabular}

Ref, reference number; OR, odds ratio; Cl, confidence interval; A, advanced; C, cardia; D, diffuse; E, early; I, intestinal; M, mixed; N, non-cardia; O, overall; IgGAb, immunoglobulin $\mathrm{G}$ antibody test; $U \& H$, rapid urease test and histological evaluation; $F$, frequency matching; $J$, adjusted for covariates.

Table 3. Subgroup analysis of SORs and $95 \% \mathrm{Cls}$ according to the test for H. pylori, and the type of OR

\begin{tabular}{lcccccc}
\hline & \multicolumn{2}{c}{ ELISA } & & \multicolumn{2}{c}{ Adjusted OR } \\
\cline { 2 - 3 } \cline { 5 - 6 } & $\begin{array}{c}\text { No. of } \\
\text { articles }\end{array}$ & SOR (95\% CI) & & $\begin{array}{c}\text { No. of } \\
\text { articles }\end{array}$ & SOR (95\% CI) \\
\hline OGC & 7 & $1.88(1.30,2.72)$ & & 6 & $1.79(1.15,2.77)$ \\
EGC & 3 & $2.31(0.93,5.75)$ & & 2 & $3.11(2.36,4.10)$ \\
CGC & 2 & $2.95(2.19,3.98)$ & & 2 & $2.95(2.19,3.98)$ \\
NGC & 2 & $3.16(2.50,4.00)$ & & 2 & $3.16(2.50,4.00)$ \\
DGC & 2 & $1.64(0.43,6.20)$ & & 2 & $1.64(0.43,6.20)$
\end{tabular}

SOR, summary odds ratio; $\mathrm{Cl}$, confidence interval; OR, odds ratio; ELISA, enzyme-linked immunosorbent assay; $\mathrm{O}$, overall; GC, gastric cancer; $\mathrm{E}$, early; C, cardia; $N$, non-cardia; $D$, diffuse. garding how $H$. pylori leads to gastric cancer, such as atopic gastritis or intestinal metaplasia [52,53], additional studies are needed among Koreans to elucidate this mechanism.

A statistically significant SOR of $H$. pylori for gastric cancer was found for EGC (SOR, 2.88; $95 \% \mathrm{Cl}, 1.55$ to 5.38), but not for AGC (SOR, 1.54; $95 \% \mathrm{Cl}, 0.39$ to 6.08). These findings should be interpreted with caution because only two studies evaluated AGC.

The present systematic review had some limitations. First, all 11 articles were case-control studies. The case group in the study of Gwack et al. [23] was unlike the others in that the data source was a cohort, but the study design incorporated a control group within the cohort (a nested case-control study). Moreover, the other studies had a significant risk of uncon- 


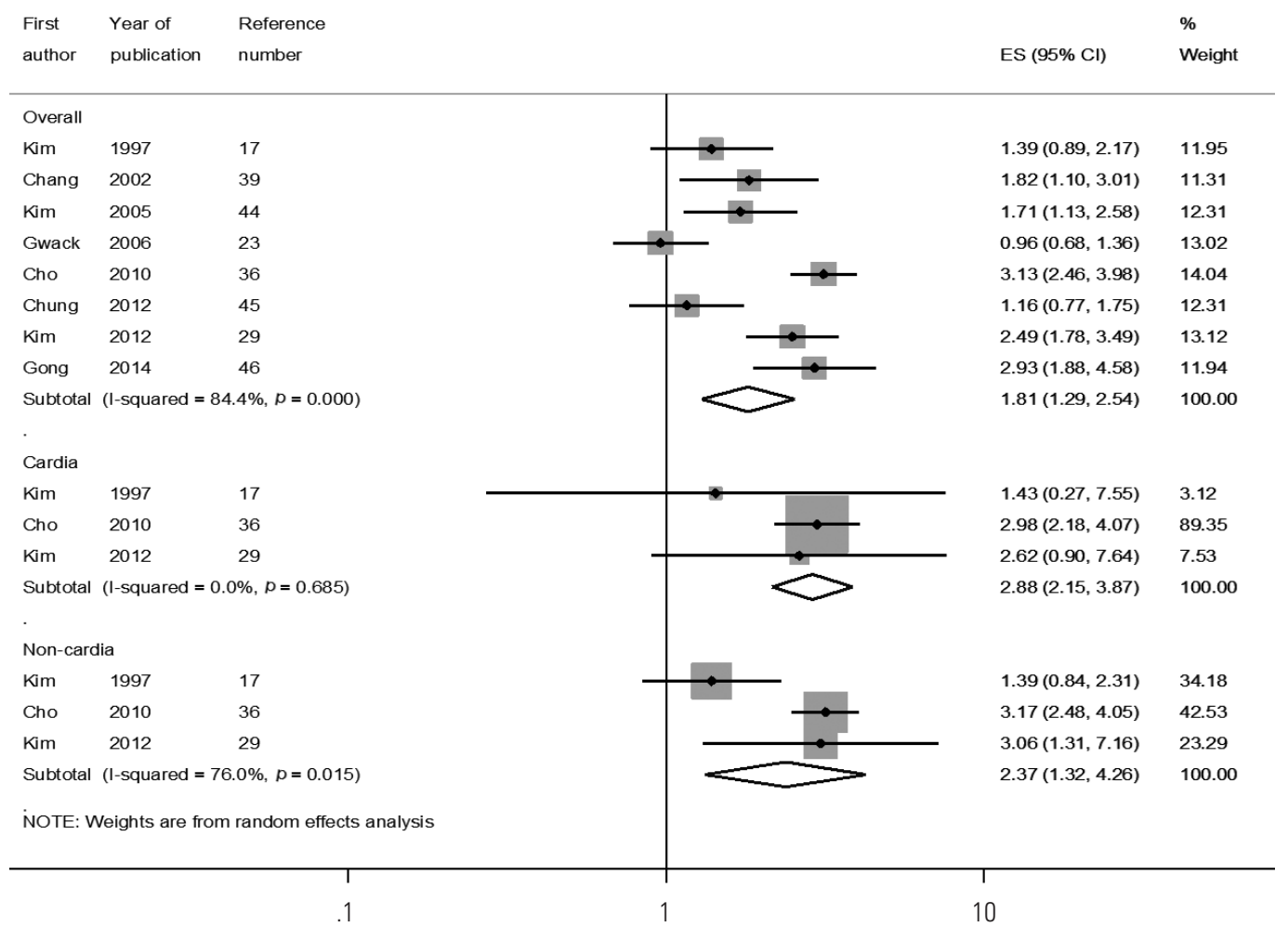

Figure 2. Summary effect size (ES) of Helicobacter pylori infection on overall, cardia, and non-cardia gastric cancer in Korean.

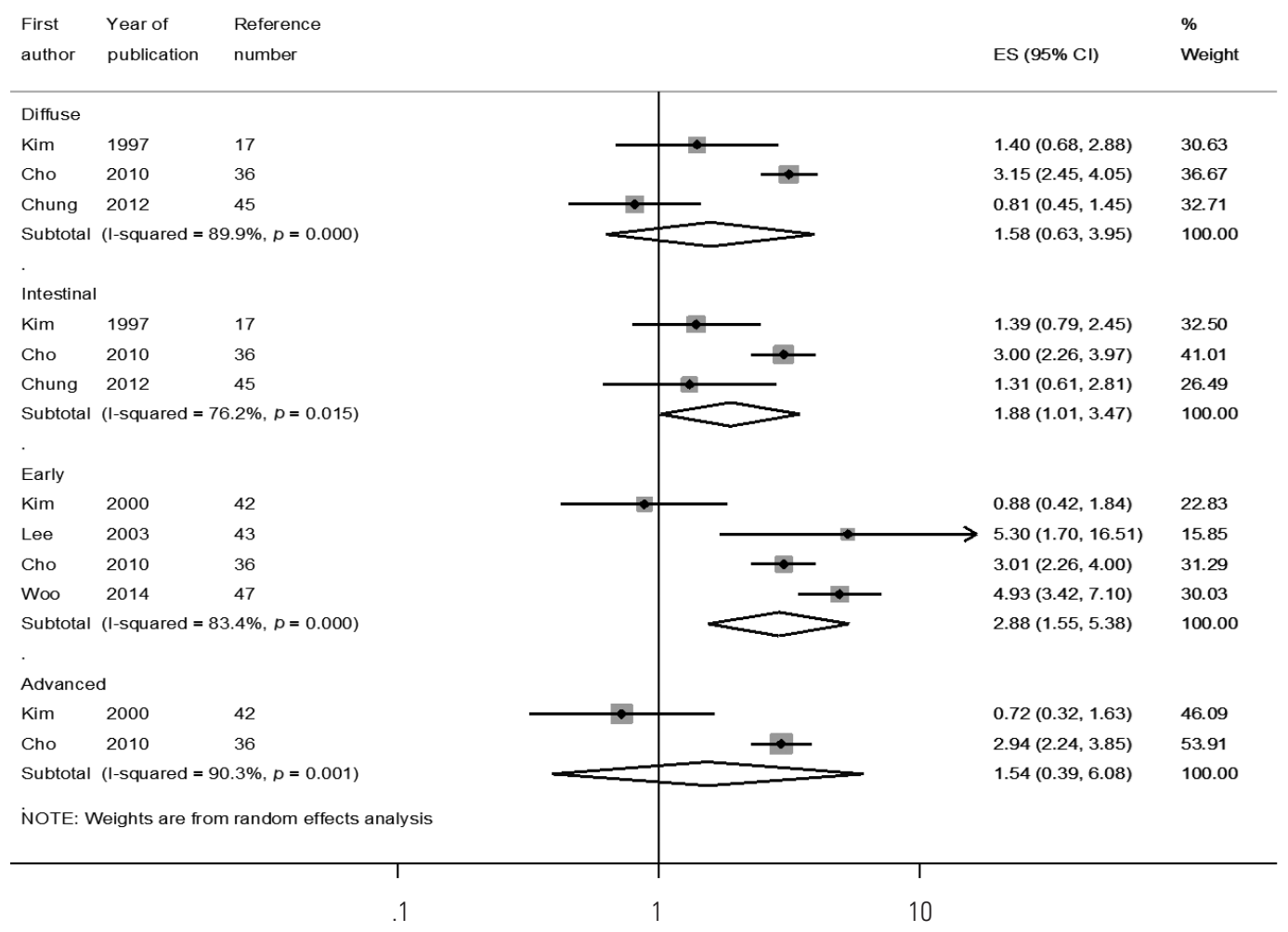

Figure 3. Summary effect size (ES) of Helicobacter pylori infection on diffuse type, intestinal type, early, and advanced gastric cancer in Korean. 
trolled biases in that they were all hospital-based case-control studies with outpatient subjects [54]. The H. pylori infection rate may be different in the general public, which could cause problems regarding the inferences drawn in those studies [55]. Considering this limitation, subgroup analyses were carried out of studies reporting FORs and AORs. Additionally, only two articles addressed AGC and one article addressed MGC, and only Gwack et al. [23] obtained information on cytotoxin-associated antigen and vacuolating cytotoxin, which are known to be the virulence factors of $H$. pylori that mediate carcinogenesis $[11,57]$. Additional studies are required to address these limitations.

\section{CONCLUSION}

Chronic H. pylori infection was found to increase the risk of gastric cancer by 1.81 times in Koreans, with the highest risk observed for CGC and EGC (SOR = 2.88 for both). Clinical epidemiologic studies are needed on the effects of treatments intended to eradicate $H$. pylori [58], and such a study is currently being conducted on patients with $\mathrm{H}$. pylori with the goal of gastric cancer prevention.

\section{ACKNOWLEDGEMENTS}

This research was supported by the 2016 scientific promotion program funded by Jeju National University.

\section{CONFLICT OF INTEREST}

The authors have no conflicts of interest associated with the material presented in this paper.

\section{ORCID}

Jong-Myon Bae http://orcid.org/0000-0003-3080-7852

Eun Hee Kim http://orcid.org/0000-0002-1065-1080

\section{REFERENCES}

1. Jemal A, Bray F, Center MM, Ferlay J, Ward E, Forman D. Global cancer statistics. CA Cancer J Clin 2011;61(2):69-90.

2. Crew KD, Neugut Al. Epidemiology of gastric cancer. World J Gastroenterol 2006;12(3):354-362.

3. Howson CP, Hiyama T, Wynder EL. The decline in gastric can- cer: epidemiology of an unplanned triumph. Epidemiol Rev 1986;8:1-27.

4. Bertuccio P, Chatenoud L, Levi F, Praud D, Ferlay J, Negri E, et al. Recent patterns in gastric cancer: a global overview. Int J Cancer 2009;125(3):666-673.

5. Blaser MJ. Helicobacter pylori and gastric diseases. BMJ 1998;316(7143):1507-1510.

6. Konturek PC, Konturek SJ, Brzozowski T. Gastric cancer and Helicobacter pylori infection. J Physiol Pharmacol 2006;57 Suppl 3:51-65.

7. Correa P. Gastric cancer: two epidemics? Dig Dis Sci 2011;56 (5):1585-1586.

8. Song M, Kang D, Yang JJ, Choi JY, Sung H, Lee Y, et al. Age and sex interactions in gastric cancer incidence and mortality trends in Korea. Gastric Cancer 2015;18(3):580-589.

9. Kim JI, Kim SG, Kim N, Kim JG, Shin SJ, Kim SW, et al. Changing prevalence of upper gastrointestinal disease in 28893 Koreans from 1995 to 2005. Eur J Gastroenterol Hepatol 2009;21 (7):787-793.

10. Marshall BJ, Warren JR. Unidentified curved bacilli in the stomach of patients with gastritis and peptic ulceration. Lancet 1984;1(8390):1311-1315.

11. Wroblewski LE, Peek RM Jr. Helicobacter pylori in gastric carcinogenesis: mechanisms. Gastroenterol Clin North Am 2013;42 (2):285-298.

12. Parkin DM. The global health burden of infection-associated cancers in the year 2002. Int J Cancer 2006;118(12):30303044.

13. Herrera V, Parsonnet J. Helicobacter pylori and gastric adenocarcinoma. Clin Microbiol Infect 2009;15(11):971-976.

14. EUROGAST Study Group. An international association between Helicobacter pylori infection and gastric cancer. Lancet 1993;341(8857):1359-1363.

15. Helicobacter and Cancer Collaborative Group. Gastric cancer and Helicobacter pylori: a combined analysis of 12 case control studies nested within prospective cohorts. Gut 2001;49 (3):347-353.

16. Cavaleiro-Pinto M, Peleteiro B, Lunet N, Barros H. Helicobacter pylori infection and gastric cardia cancer: systematic review and meta-analysis. Cancer Causes Control 2011;22(3):375387.

17. Kim HY, Cho BD, Chang WK, Kim DJ, Kim YB, Park CK, et al. Helicobacter pylori infection and the risk of gastric cancer among the Korean population. J Gastroenterol Hepatol 1997; 12(2):100-103. 
18. Lee BM, Jang JJ, Kim JS, You YC, Chun SA, Kim HS, et al. Association of Helicobacter pylori infection with gastric adenocarcinoma. Jpn J Cancer Res 1998;89(6):597-603.

19. Shin A, Shin HR, Kang D, Park SK, Kim CS, Yoo KY. A nested case-control study of the association of Helicobacter pylori infection with gastric adenocarcinoma in Korea. Br J Cancer 2005;92(7):1273-1275.

20. Bae JM, Lee EJ, Guyatt G. Citrus fruit intake and stomach cancer risk: a quantitative systematic review. Gastric Cancer 2008; 11(1):23-32.

21. Higgins JP, Thompson SG. Quantifying heterogeneity in a meta-analysis. Stat Med 2002;21(11):1539-1558.

22. Harbord RM, Egger M, Sterne JA. A modified test for smallstudy effects in meta-analyses of controlled trials with binary endpoints. Stat Med 2006;25(20):3443-3457.

23. Gwack J, Shin A, Kim CS, Ko KP, Kim Y, Jun JK, et al. CagA-producing Helicobacter pylori and increased risk of gastric cancer: a nested case-control study in Korea. Br J Cancer 2006;95 (5):639-641

24. Ko KP, Park SK, Park B, Yang JJ, Cho LY, Kang C, et al. Isoflavones from phytoestrogens and gastric cancer risk: a nested casecontrol study within the Korean Multicenter Cancer Cohort. Cancer Epidemiol Biomarkers Prev 2010;19(5):1292-1300.

25. Yang JJ, Yang JH, Kim J, Ma SH, Cho LY, Ko KP, et al. Soluble cMet protein as a susceptible biomarker for gastric cancer risk: a nested case-control study within the Korean Multicenter Cancer Cohort. Int J Cancer 2013;132(9):2148-2156.

26. Yang JJ, Ko KP, Cho LY, Shin A, Gwack J, Chang SH, et al. The role of TNF genetic variants and the interaction with cigarette smoking for gastric cancer risk: a nested case-control study. BMC Cancer 2009;9:238.

27. Ko KP, Park SK, Cho LY, Gwack J, Yang JJ, Shin A, et al. Soybean product intake modifies the association between interleukin-10 genetic polymorphisms and gastric cancer risk. J Nutr 2009;139(5):1008-1012.

28. Kim Y, Shin A, Gwack J, Ko KP, Kim CS, Park SK, et al. EpsteinBarr virus antibody level and gastric cancer risk in Korea: a nested case-control study. Br J Cancer 2009;101(3):526-529.

29. Kim JY, Lee HS, Kim N, Shin CM, Lee SH, Park YS, et al. Prevalence and clinicopathologic characteristics of gastric cardia cancer in South Korea. Helicobacter 2012;17(5):358-368.

30. Shin CM, Kim N, Cho SI, Kim JS, Jung HC, Song IS. Association between alcohol intake and risk for gastric cancer with regard to ALDH2 genotype in the Korean population. Int J Epidemiol 2011;40(4):1047-1055.
31. Kim N, Park YS, Cho SI, Lee HS, Choe G, Kim IW, et al. Prevalence and risk factors of atrophic gastritis and intestinal metaplasia in a Korean population without significant gastroduodenal disease. Helicobacter 2008;13(4):245-255.

32. Kang KP, Lee HS, Kim N, Kang HM, Park YS, Lee DH, et al. Role of intestinal metaplasia subtyping in the risk of gastric cancer in Korea. J Gastroenterol Hepatol 2009;24(1):140-148.

33. Hwang JJ, Lee DH, Lee AR, Yoon H, Shin CM, Park YS, et al. Characteristics of gastric cancer in peptic ulcer patients with Helicobacter pylori infection. World J Gastroenterol 2015;21 (16):4954-4960.

34. Kim HJ, Kim N, Kim HY, Lee HS, Yoon H, Shin CM, et al. Relationship between body mass index and the risk of early gastric cancer and dysplasia regardless of Helicobacter pylori infection. Gastric Cancer 2015;18(4):762-773.

35. Shin CM, Kim N, Yang HJ, Cho SI, Lee HS, Kim JS, et al. Stomach cancer risk in gastric cancer relatives: interaction between Helicobacter pylori infection and family history of gastric cancer for the risk of stomach cancer. J Clin Gastroenterol 2010;44(2): e34-e39.

36. Cho SJ, Choi IJ, Kim CG, Lee JY, Kook MC, Seong MW, et al. Helicobacter pylori seropositivity is associated with gastric cancer regardless of tumor subtype in Korea. Gut Liver 2010;4 (4):466-474

37. Cho SJ, Choi IJ, Kim CG, Kook MC, Lee JY, Kim BC, et al. Risk factors associated with gastric cancer in patients with a duodenal ulcer. Helicobacter 2010;15(6):516-523.

38. Nam JH, Choi IJ, Cho SJ, Kim CG, Lee JY, Nam SY, et al. Helicobacter pylori infection and histological changes in siblings of young gastric cancer patients. J Gastroenterol Hepatol 2011; 26(7):1157-1163.

39. Chang WK, Kim HY, Kim DJ, Lee J, Park CK, Yoo JY, et al. Association between Helicobacter pylori infection and the risk of gastric cancer in the Korean population: prospective casecontrolled study. J Gastroenterol 2001;36(12):816-822.

40. Kim HJ, Lee SS, Choi BY, Kim MK. Nitrate intake relative to antioxidant vitamin intake affects gastric cancer risk: a case-control study in Korea. Nutr Cancer 2007;59(2):185-191.

41. Kim HJ, Kim MK, Chang WK, Choi HS, Choi BY, Lee SS. Effect of nutrient intake and Helicobacter pylori infection on gastric cancer in Korea: a case-control study. Nutr Cancer 2005;52(2): 138-146.

42. Kim YS, Park HA, Kim BS, Yook JH, Lee MS. Efficacy of screening for gastric cancer in a Korean adult population: a case-control study. J Korean Med Sci 2000;15(5):510-515. 
43. Lee SA, Kang D, Shim KN, Choe JW, Hong WS, Choi H. Effect of diet and Helicobacter pylori infection to the risk of early gastric cancer. J Epidemiol 2003;13(3):162-168.

44. Kim DS, Lee MS, Kim YS, Kim DH, Bae JM, Shin MH, et al. Effect modification by vitamin $C$ on the relation between gastric cancer and Helicobacter pylori. Eur J Epidemiol 2005;20(1):6771.

45. Chung SJ, Park MJ, Kang SJ, Kang HY, Chung GE, Kim SG, et al. Effect of annual endoscopic screening on clinicopathologic characteristics and treatment modality of gastric cancer in a high-incidence region of Korea. Int J Cancer 2012;131(10): 2376-2384.

46. Gong EJ, Ahn JY, Jung HY, Lim H, Choi KS, Lee JH, et al. Risk factors and clinical outcomes of gastric cancer identified by screening endoscopy: a case-control study. J Gastroenterol Hepatol 2014;29(2):301-309.

47. Woo HD, Lee J, Choi IJ, Kim CG, Lee JY, Kwon O, et al. Dietary flavonoids and gastric cancer risk in a Korean population. Nutrients 2014;6(11):4961-4973.

48. Brenner H, Arndt V, Stegmaier C, Ziegler H, Rothenbacher D. Is Helicobacter pylori infection a necessary condition for noncardia gastric cancer? Am J Epidemiol 2004;159(3):252-258.

49. Hansen S, Vollset SE, Derakhshan MH, Fyfe V, Melby KK, Aase S, et al. Two distinct aetiologies of cardia cancer; evidence from premorbid serological markers of gastric atrophy and Helicobacter pylori status. Gut 2007;56(7):918-925.

50. Sim YK, Kim CY, Jeong YJ, Kim JH, Hwang Y, Yang DH. Changes of the clinicopathological characteristics and survival rates of gastric cancer with gastrectomy: 1990s vs early 2000s. J Korean Gastric Cancer Assoc 2009;9(4):200-206 (Korean).

51. Kang KJ, Lee JH. Characteristics of gastric cancer in Korea: with an emphasis on the increase of the early gastric cancer (EGC). J Korean Med Assoc 2010;53(4):283-289 (Korean).

52. Correa P. Helicobacter pylori and gastric cancer: state of the art. Cancer Epidemiol Biomarkers Prev 1996;5(6):477-481.

53. Wroblewski LE, Peek RM Jr, Wilson KT. Helicobacter pylori and gastric cancer: factors that modulate disease risk. Clin Microbiol Rev 2010;23(4):713-739.

54. Lunet N, Azevedo A. On the comparability of populationbased and hospital-based case-control studies. Gac Sanit 2009;23(6):564.

55. Peleteiro B, Lunet N, Barros R, La Vecchia C, Barros H. Factors contributing to the underestimation of Helicobacter pyloriassociated gastric cancer risk in a high-prevalence population. Cancer Causes Control 2010;21(8):1257-1264.

56. Bae JM, Kim EH. Hormone replacement therapy and risk of breast cancer in Korean women: a quantitative systematic review. J Prev Med Public Health 2015;48(5):225-230.

57. Huang JQ, Zheng GF, Sumanac K, Irvine EJ, Hunt RH. Metaanalysis of the relationship between cagA seropositivity and gastric cancer. Gastroenterology 2003;125(6):1636-1644.

58. Lee S, Park JM, Park SH, Kim EH, Hahm KB. The Korean perspective of Helicobacter pylori infection: lessons from Japan policy to prevent gastric cancer. J Cancer Prev 2013;18(2):107112. 